\title{
Early ceramic styles and technologies in the Aegean and the Balkans: retrospect and prospects
}

\author{
Lily Bonga \\ Institute for Aegean Prehistory, Study Center for East Crete, Pacheia Ammos, GR \\ lilybonga@gmail.com
}

\begin{abstract}
Ceramics have always played a central role in defining the Neolithic period in southeastern Europe. Early Neolithic ceramic assemblages, forming techniques, clay recipes, shapes, decoration, and vessel function have been traditionally used to establish the chronology and cultural groups of a region based on a handful of purported type-sites. This paper presents a critical review of the literature on Early Neolithic pottery in Greece, highlighting how preconceptions shaped the research and interpretation of the data of not only the ceramics themselves, but also how those interpretive conclusions were projected into other aspects of Early Neolithic life, such as the gender and status of potters and the socio-functional use of pottery. The recent reevaluation of old and new absolute dates through Bayesian analysis, statistical modelling, and stratigraphic considerations has also helped to provide a more nuanced use of relative pottery chronologies. New archaeological evidence from Northern Greece as well as reevaluations of Knossos and the Franchthi Cave are highlighted.
\end{abstract}

KEY WORDS - chronology; pottery; Impresso; Knossos; Franchthi; Greek Macedonia

\section{Zgodnji keramični stili in tehnologije na območju Egejskega morja in Balkana: pogled nazaj in naprej}

IZVLEČEK - Vjugovzhodni Evropi je imela keramika pri opredeljevanju neolitika vedno osrednjo vlogo. Na podlagi podatkov, pridobljenih na maloštevilnih domnevno tipičnih najdiščih, se je v tej regiji za vzpostavljanje kronologije in kulturnih skupin tradicionalno uporabljalo zgodnje neolitske keramične zbire, tehnike oblikovanja, lončarske recepte, oblike, okras in namembnost posod. V članku ponudimo kritično presojo literature o zgodnje neolitski lončenini v Grčiji, pri čemer izpostavljamo načine, kako so pristranski pogledi oblikovali raziskave in interpretacije različne vrste podatkov, ne samo same keramike, ampak tudi kako so s takšnimi zaključki interpretirali tudi druge vidike zgodnje neolitskega življenja kot sta spol in status lončarjev ter družbeno-funkcionalna raba lončenine. Za bolj raznoliko rabo relativnih kronologij, ki temeljijo na lončenini, si lahko pomagamo predvsem z nedavno predstavljenimi novimi ovrednotenji starih in novih absolutnih datumov, ki so bili izvedeni z Bayesovo analizo, ter s statističnim modeliranjem in ovrednotenjem stratigrafije. V članku predstavljamo tudi nove arheološke podatke iz severne Grčije ter ponovno ovrednotenje podatkov iz Knossosa na Kreti in jame Franchthi na Peloponezu.

KLJUČNE BESEDE - kronologija; lončenina; Impresso; Knossos; Franchthi; grška Makedonija

\section{Introduction}

The Neolithic period in Greece was traditionally believed to have begun around $7000 \mathrm{BC}$ based on early absolute dates from the 1960s from a handful of sites, including Nea Nikomedia, Argissa, Sesklo, Achil- leion, the Franchthi Cave, and Knossos on Crete (Fig. 1). This early date seemed to support the relative chronology and led to comparisons between the Near East, Anatolia, and southeastern Europe. It also 
paved the way for pejorative descriptions of the pottery as primitive and simple, fitting presumed evolutionary paradigms of technological development. This fact is evident in the names (Frühkeramikum, Proto-Sesklo, Vor-Sesklo) and their definitions (early pottery, early painted, developed monochrome) of the first relative chronology for the Early Neolithic period for Thessaly. These sites have served as typesites for the Early Neolithic period in their respective regions ever since, but can no longer do so, as recent work in Northern Greece, Crete, the Cyclades, and Western Anatolia has expanded and enhanced the dataset.

\section{Traditional chronology of the Early Neolithic period in Greece}

The traditional relative chronology of Neolithic Greece was primarily created in Thessaly due to early excavation and survey work in the area, and was based on surface treatment and decoration (Tsountas 1908; Wace, Thompson 1912). The relative chronology for Thessaly was established by Vladimir Milojčić (1959) and it became canonical (Theocharis 1973). Scholars in Central and Southern Greece (e.g., Weinberg 1962; 1970) tried to correlate their ceramics to those of Thessaly as based on Milojčić's system, but did not make chronological subdivisions based on decorated ceramics. Early Neolithic Greek Macedonia was unknown in Milojčićs time.

Concerning the Early Neolithic, a tripartite system was established. It consists of the Frühke-

Fig. 1. Neolithic sites mentioned in the text with absolute dates within 6600-5900 cal BC. Numbers 3, 6, 7 without absolute dates. 1 Ulucak Höyük; 2 Cukuriçi Höyük; 3 Pelekita Cave, Crete; 4 Knossos, Crete; 5 Akrotiri, Santorini; 6 Ayia Gala, Chios; 7 Emporio, Chios; 8 Dikili Tash; 9 Giannitsa B; 10 Axios A; 11 Nea Nikomedia; 12 Kolindros- Paliambela; 13 Revenia-Korinos; 14 Servia-Varytimidis; 15 Mavropigi-Filotsairi; 16 Theopetra Cave; 17 Prodromos; 18 Otzaki Magoula; 19 Argissa Magoula; 20 Sesklo; 21 Achilleion; 22 Franchthi Cave. ramikum, a purely monochrome phase, the ProtoSesklo with developed monochrome pottery and limited use of painting, and the Vor-Sesklo (Pre-Sesklo) in which painted pottery was more common than before. In this traditional scheme, the first painted pottery in Greece was conceived of as redpainted decoration, typically red or reddish or buffcoloured surfaces.

Milojčić (1960) later argued for the existence of a Pre-Ceramic phase in Greece of chronological significance in the Balkans based on analogy with the Pre-Pottery Neolithic (PPN) of the Near East. Late, the 'Magoulitsa sub-phase' was added at the end of Vor-Sesklo based on the finds from Otzaki Magoula (Milojčić-von Zumbusch 1971; Müller 1988; 1994; Reingruber 2011; 2015). The 'Magoulitsa phase or culture' was defined by the use of impressed, incised, and finger-pinched decoration, subdivided into an earlier ('barbotine') and a later ('cardium') phase (Milojčić-von Zumbusch 1971.146-148; Reingruber et al. 2017.41-42). It was thought to be of Balkan influence (Milojčić, Milojčić-von Zumbusch 1971.82ff) and allowed for correlations between the two regions (Milojcici 1959.10-11, 31-32) as this type of decoration was recognized since the beginning of the $20^{\text {th }}$ century as an "independent cultural phenomenon in the northern Balkans" (e.g., 'nail-decorated horizon'; Childe 1929.75-76, 79; 'Na-

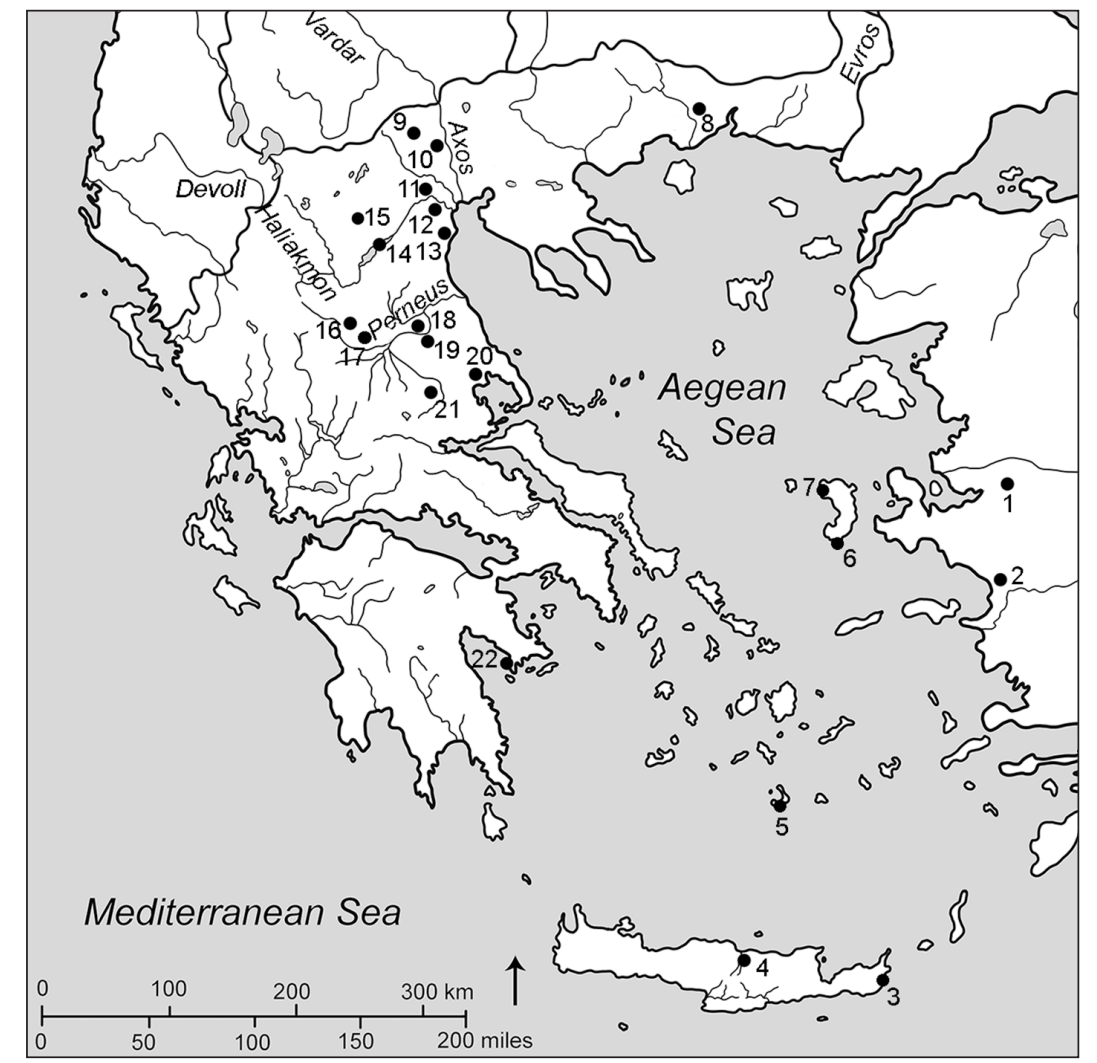


gelgeritzte'; Banner 1929; 1935.122-123; Raczky 2012.9).

As the culture-history approach fell out of fashion, the tripartite chronology of Early Neolithic Thessaly was relabelled under the more neutral divisions of Early Neolithic 1, 2, and 3 (Wijnen 1981). Later, the 'Preceramic' was renamed 'Initial Neolithic' (Perlès $2001.43, n .8)$. Local regional differences in ceramics also began to be considered within Thessaly, such as the disappearance of painted pottery by the end of the Proto-Sesklo phase at some sites in and directly around the plain of Larisa, like Sesklo and Argissa Magoula. Yet in the Vor-Sesklo period, painted pottery, "at sites in or around the plain of Karditsa it does not vanish, but coexists with plastic decoration" (Wijnen 1981.36).

Lastly, what is significant about the relative chronology of Greece as established by Milojčić (1949a; $1949 b ; 1950 / 51 ; 1959)$ is that his chronology was used as a template of cultural development for the whole of south-eastern Europe in the Neolithic (e.g., Starčevo in Serbia, Körös in Hungary, Criş in Romania) despite some objections (e.g., Nandris 1970; Schubert 1999; 2005) (Fig. 2). For instance, by analogy with Greece, a hypothetical monochrome phase was proposed for the definition of Proto-Starčevo phase (Srejović 1973) and Starčevo Ia (Lazarovici 1979). Milojčićs four-stage relative chronology for the Neolithic period was also subsequently modified in its application in other regions (e.g., Arandjelović-Garašanin 1954; Grbić 1957; Dimitrijević 1969; 1974; Srejović 1971; Makkay 1965; 1969; 1987).

\section{Aspects related to the Impresso-style}

Impressed, incised, and finger-pinched decoration of the 'Magoulitsa phase' is today referred to in the literature of Neolithization of Europe under the umbrella term of 'impresso', which encompasses all types of plastic surface decoration irrespective of the fabric, vessel shape, method of surface manipulation (finger or tool), stylistic differences (dense $v s$. sparse, organized into motifs $v s$. random), or precise chronological correlations (Vuković 2013.661-660), and is cited as evidence of connectivity and mobility between vast geographic areas (e.g., Adriatic, Balkans, Anatolia, North Africa, the Near East, and the Black Sea) (Ciilingiroglu 2010; 2016; Gaskevych 2010; 2011; Güldoğan 2010).

The term 'impresso' was originally used to describe pottery decorated with incisions made with pointed tools and impressions of cockle shells (formerly classed as Cardium edulis but now classified as $\mathrm{Ce}$ rastoderma edule) in the Early Neolithic period of the Adriatic; impressions of fingernails, fingertips, and finger-pinches were rarely used in this region. Conversely, in the Balkans, cockle shells were never used for impressions (Coleman 1992.254); instead 'pseudo-impresso' or 'comb-impressed' was used to describe impressions and incisions made with tools or fingers (Vukovic 2013.658). The ceramic tradition in the central Balkans also remained distinct from that of the Adriatic coastline (both style and manufacturing techniques) (Spataro 2009).

The subcategory of 'barbotine' (barbotin) was thought to be a chronological marker for the Early Neolithic Balkan-Anatolian complex in the Central Balkans (e.g., proto-Starčevo) (Vuković 2013.671). Barbotine was defined as an additive decorative style in which wet clay slurry is added to create a lumpy, irregular surface, sometimes with ridges or rows in ornamental compositions (stepped, channelled, arcaded) (Aranđelović-Garašanin 1954); pseudo-bar-

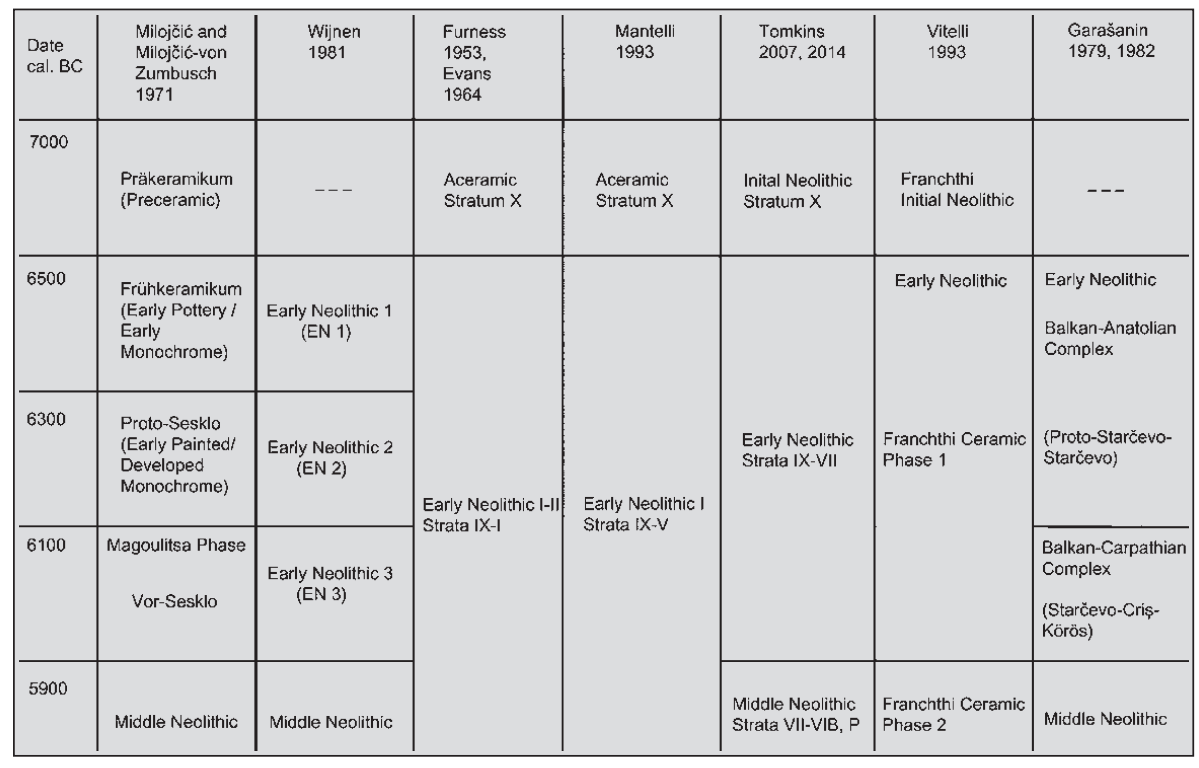

Fig. 2. Traditional chronology of Early Neolithic Greece, as based on Thessaly and in reference to the Balkans. 
botine is defined as a slurry surface and small clay granules (Vuković 2013.662). Several other descriptive terms or phrase have been applied (e.g., 'wheatgrain': Dimitrijevic 1974.67; Sekereš 1974.192; 'fir branches': Benac 1979.380; "an endless flock of birds in flight": Vetnic 1974.130). The distinction between 'impresso' and 'barbotine' found in the literature was believed to have chronological meaning, but this is no longer the case (Vuković 2013.660). Complicating the picture is the fact that the terms 'impresso' and 'barbotine' are used differently in Greece from the rest of the Balkans.

In Greece, the 'impresso' pottery associated with the 'Magoulitsa phase or culture' of the Vor-Seklo period was subdivided into an early 'barbotine' phase consisting of finger pinches and nail impressions and a later 'cardium' phase, in which tools were used to create the impressions, excluding the use of cockle shells (Reingruber et al. 2017.41-42). These subphases were based on Otzaki Magoula (Müller 1988; 1994; Reingruber 2011) but were not grounded on stratigraphic reality (Reingruber et al. 2017.42), nor does the small amount of highly curated published material add much to support to this claim (Tsitrstoni 2009.45).

Furthermore, the ceramic sequence of the 'Magoulitsa phase' as found at Otzaki was not confirmed at Sesklo, where painted pottery disappeared before the end of the period, when parts of the settlement were destroyed by fire (Andreou et al. 1996.540; Wijnen 1981.11) and perhaps followed by a hiatus during Vor-Sesklo period (Wijnen 1981). It has also been suggested that the absence of the 'Magoulitsa phase' at Sesklo or other sites in eastern Thessaly is not chronological, but rather geographical, as impressed, incised, and finger-pinched pottery is documented in Thessaly both at the end of the Early Neolithic (e.g., Nessonis I, Gediki, Argissa Magoula, Otzaki Magoula) and in the beginning of the Middle Neolithic (e.g., Magoulitsa, Achilleion, Bardali, Koutroulou Magoula). Therefore, any distribution maps of Early Neolithic sites based on Gallis' Atlas (Gallis 1992) should be seriously questioned because they were constructed using relatively dated sites based on the presence or absence of monochrome, painted, or impresso decoration of surface sherds (Reingruber 2011.297).

A greater degree of ceramic variability is now recognized both at the intra site and regional levels (Kotsakis 1983; 2008) within the same chronological period (Gallis 1987; Coleman 1992), which sug- gests that comparative conclusions from excavation sequences presumed to be typical (e.g., as Mottier 1981 does with Otzaki) should not be taken as representative of the wider region (Andreou et al. 1996. 542).

\section{Current chronology of the Early Neolithic pe- riod in Greece}

The main weakness in Milojčićs relative chronology was its complete lack of absolute dates, which were also absent from the rest of south-eastern Europe. Current absolute dates from Thessaly and Macedonia date the Early Neolithic period to $c$. 6500-5900 BC (Reingruber et al. 2017; Tsirtsoni 2016; Maniatis 2014; Perlès et al. 2013; Lespez et al. 2013; Dou$k a$ et al. 2017; Perlès 2001.109-110), although some sites may begin as early as $c .6600 \mathrm{BC}$. These dates are comparable to new data from western Turkey (Anatolia).

Current absolute dating of the Pre-Ceramic phase prevents its definition of being contemporary with the PPN Pre-pottery Neolithic of the Near East of Cyprus (Reingruber 2015.153-154). This phase also remains to be securely documented anywhere in Greece, as its definition was primarily based on small areas of exposure in thin strata just above bedrock, or sterile soil and often with 'intrusive' sherds or other ceramic material such as figurines (Nandris 1970.196-201; Reingruber 2008; 2011; 2015; Reingruber, Thissen 2009; Bloedow 1992-1993; Nowicki 2014.48-60).

Similarly, neither a Pre-Ceramic nor an Early Monochrome (ger. Frühkeramikum) phase is found elsewhere in areas to the north (e.g., Republic of Northern Macedonia: Stojanovski et al. 2014; Naumov 2009.4); Albania (e.g., Vlush, Konispol Cave: personal comm.; Adoni 2018); Bulgaria (e.g., Krainitsi I, Koprivets I and Polyanitsa-platato I: Krauß et al. 2014.52; Stefanova 1996; Krauß 2006.161-162; 2008.119-121; 2011); and probably Hungary and Romania (Biagi, Spataro 2005).

The existence of an Early Monochrome (Frühkeramikum) phase can also be questioned on the same contentious criteria as the Pre-ceramic deposits (e.g., limited exposure, thin deposits, small sample). Given the supposed rarity of early painted pottery in the Vor-Sesklo phase in general, and the fact that this early painted decoration was often applied only on a small part of the vessel (e.g., near rims), it cannot be convincingly argued that painted pottery was not 
in use. A more accurate statement would be that painted pottery was not found in the lowest levels of small horizontal exposure, often in secondary refuse pits. Yet the use of painted pottery cannot be ruled out due to these small sample sizes and contexts (e.g., in pits).

Giving these individual site phases/levels chronological meaning beyond the site level by making them into regional phases of long temporal duration may be an artificial construction by modern archaeologists. For instance, Karen D. Vitelli (1993b.46, n. 18) has pointed out how excavation methodology affects the data; without the sherds recovered from sieving, the earliest levels at the Franchthi Cave were monochrome and the ceramic development appeared to conform to the Thessalian sequence, but when she added the sherds recovered from sieving, this development was invalidated. In contrast to the excavation procedures of the Franchthi Cave, where dry and wet sieving were employed, the material from Sesklo was not even dry sieved (Wijnen 1981. 17), which may have impacted its interpretation.

\section{New evidence from Greek Macedonia}

New data from Northern Greece highlights the need to carefully integrate excavation stratigraphy with ceramics and absolute dates, as well as identify regional differences with the same period. For instance at Mavropigi-Filotsairi in Western Macedonia, the excavators identified three phases belonging to the Early Neolithic period; these phases seem supported by absolute date. These phases were primarily based on the stratigraphy of a central feature of the site (the central origma), which was interpreted as a semi-subterranean house that eventually became a ground-level structure (Karamitrou-Mentessidi et al. 2016.51-53).

On its own, a simple presentation of the stratigraphy and ceramics from the central origma would also appear to follow the Thessalian sequence, with the lowest levels above sterile soil devoid of ceramics but containing other cultural remains, followed by thin levels with monochrome pottery, and later levels that included painted, impressed, and incised pottery (Bonga 2017). Yet upon close inspection of the sherds (e.g., a few joins between Phase I and the first passes of Phase II and the nature of the sherds themselves: small, abraded, reused, use of red-slip), the lack of complete vessels, and the rarity of complete profiles suggests that these pieces were discarded material that may or may not date to one temporal moment. Similar depositional practices were suggested at the Franchthi Cave, where most deposits were determined to be secondary and suggestive of periodic cleaning of areas rather than containing material from a specific activity (Vitelli 1993b.31).

When other deposits at Mavropigi-Filotsairi are taken into account, other complications arise. The use of red-painted pottery on a white slip made of a calcareous material, though rare, is documented in the Vor-Sesklo phase both at Paliambela (Saridaki et al. 2019) and at Mavropigi-Filotsairi (Bonga 2017.378); this type of decoration is characteristic of the Middle Neolithic in Thessaly. The distinction between the use of painted decoration on a slip, white slip, or unburnished surface may be related to regional differences and/or chronological ones. ${ }^{1}$ For example, white-on-red painted pottery in the traditional relative chronology was characteristic of the Middle Neolithic in Thessaly. Yet this type of decoration in the Vor-Sesklo period appears in Central Macedonia at Nea Nikomedia (Yiouni 1996), Axos A (Chrysostomou 1996), and Yiannitsa B (Chrysostomou 1997), together with impresso. These sites date to $c$. 6300/ 6200 BC (Maniatis 2014.Fig. 2; Maniatis et al. 2015. Fig. 4).

White-on-red painted pottery from Mavropigi-Filotsairi was found in pit 106 and assigned to Phase II by the excavators. The precise date of the appearance of this type of pottery is unclear as the pit was used over time, but the absolute date $c .6200 \mathrm{BC}$ based on charred seeds (0xA-31863, 6222 $\pm 83 \mathrm{BC}$ ) may be an indicator. The central orgima in Phase II did not contain white-painted pottery. What is interesting at Mavropigi-Filotsairi is the fact that the technology (red slip, white paint) to produce white-on-red decoration was known since the Proto-Sesklo phase, as the characteristic pottery of Mavropigi-Filotsairi includes polychrome-painted pottery consisting of broad areas of motifs painted in red on a tan back-

\footnotetext{
1 Creating a distinction on the use of slips in general and as a background for painted pottery requires more investigation thanis possible based on small assemblages or applying one site (e.g., Sesklo) as a paradigm, even within a region. While a limited use of slips is documented at Sesklo in all phases and areas of the settlement, slips of various composition were used at sites in the plain of Larisa (e.g., Argissa, Otzaki, Soufli, and Melissochori Magoula) and slips were regularly used at Achilleion (Dimoula 2017. 211, 213, 215). A similar variability in the use of slips is seen in Central Macedonia at Revenia, where slips were rare while at Palaiambela slips were common, including the use of white slip (calcareous material) (Saridaki et al. 2019).
} 
ground and outlined in white paint (Fig. 3). Polychrome and red-pained pottery was preferred over white-on-red.

The impressed, incised, and finger-pinched pottery at Mavropigi-Filotsairi dates $100-200$ years earlier than that of 'Magoulitsa phase' $c .6400 / 6300$ BC (e.g. pit A, DEM-1680; western origma DEM-2697/MAMS21104; burial 3, in the central origma, OxA-V02365-54/S-EVA 10096). Many different types

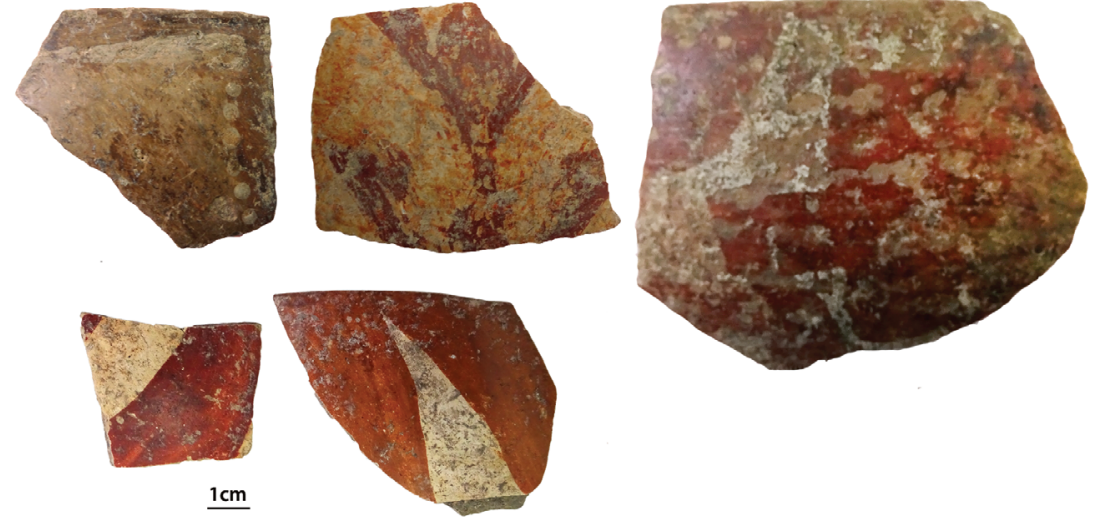

Fig. 3. Early Neolithic polychrome, white-on-red, and red-on-white painted pottery from Phase II, pit 106 at Mavropigi-Filotsairi. of surface treatments were used (Fig. 4) and this type of decoration was used alongside monochrome and painted pottery. Similarly, while few in number within a small area and sample size, decorated pottery consisting of both red-painted and finger-pinched decoration was documented in two pits (629, 630) with early dates at Paliambela (Papadakou 2011; Papadakou et al. 2015). ${ }^{2}$ These sites show the development of decorated pottery at some sites in Central and Macedonia does not match the traditional Thessalian sequence in terms of development or date.

\section{Recent re-evaluations of the Franchthi Cave in the Argolid (Peloponnese)}

At the Franchthi Cave, Vitelli (1993a.37) defined deposits below pottery-bearing levels as Ceramic Phase Zero and the Ceramic Interphase $0 / 1$ as units in each sequence located between lower deposits that contained no pottery (FCP 0) and upper deposits that contained all of the Franchthi Ceramic Phase 1 varieties. Ceramic Phase Zero is called Initial Neolithic by other scholars who conducted secondary research, but not primary analysis of the ceramic assemblage itself (e.g., Perlès 2001; Perlès et al. 2013; Reingruber, Thissen 2009; 2016).

An examination of the absolute dates and contexts from the Franchthi Cave revealed the Final Mesolithic layers (Franchthi Lithic Phase X) overlap with the dates for Initial Neolithic layers (c. 6700-6400 BC; Reingruber, Thissen 2016; Perlès et al. 2013), and this was followed by a gap in dates of at least 500 years (up to 700 years; Reingruber, Thissen 2009.758) when the cave was re-occupied around or after $5900 \mathrm{BC}$ based on these dates and ceramic parallels. 3 These gaps were perceptible in the ceramics, but were dismissed by Vitelli (1993b.26). 4

It is also worth noting that the Franchthi Cave is perhaps better described as rock shelter or abri with a small open-air site adjacent (Paralia). It is not a dark, damp, cavernous cave like those used in later periods of the Neolithic (e.g., Skoteino, Alepotrypa, Ayia Triada); nor is it an open-air settlement, and these differences of context must be taken into account. The Franchthi Cave is also located on the coast, un-

2 The interpretive situation at Palaimbela is based on absolute dates from burned animal bones (unspecified species) found in two Early Neolithic pits $(629,631)$ that have been interpreted as semi-subterranean pit-dwellings (Maniatis et al. 2015.151). Pit 629 yielded one date (DEM-2462/MAMS-12513) of $c .6400-6200$ BC (another date DEM-2461/MAMS-12512) is listed as coming from over rather than within the pit itself). Pit 629 was $2.48 \times 2.10 \mathrm{~m}$ in size (Maniatis et al. 2015.151) and contained 8.12 kilograms of pottery, consisting of 439 sherds, only one of which was red-painted without the use of a white slip (Papadakou 2011.93). Pit 629 does not seem to be a totally closed deposit, however, as historical pit 606 cuts into its southern part and because the two dates (DEM-2464/MAMS-12515, DEM-2465/MAMS12516) from pit 627 antedate pit 629, even though pit 629 is depicted on the plan (Maniatis et al. 2015.Fig. 1; Papadakou 2011.237, Fig. 2) as later than pit 627 (pit 627 is also cut into by historical pit 607 in the northern part). Pit 630 yielded three dates (DEM-2458/MAMS-12509, DEM-2459/MAMS12510, DEM-2460/ MAMS12511) falling around 6600-6400 BC (Maniatis et al. 2015.Fig. 1). The pit was approx. $1.7 \times 1.07 \mathrm{~m}$ in size and contained 1.32 kilos of pottery, consisting of 187 sherds, six of which were decorated with finger and nail pinching (Papadakou 2011.90).

3 Other gaps in the stratigraphy are also confirmed by the absolute dates, such as before Franchthi Ceramic Phase 4 (c. 5200 BC) in the beginning of the Late Neolithic (Reingruber 2008.23, Tab. 1.6; 2017; Reingruber, Thissen 2016).

4 Similar reevaluations of key Neolithic sites in later periods throughout Greece (e.g., Skoteini, Sarakenos, Cyclops, and Franchthi Caves, Dikili Tash, Sitagroi, and Servia) have also demonstrated that previous observations about the continuity of stratigraphy and ceramics cannot be substantiated (Coleman 2011.17-19; Coleman, Facorellis 2018; Nowicki 2014; Tsitrsoni 2016; 2017; Reingruber, Thissen 2009). 

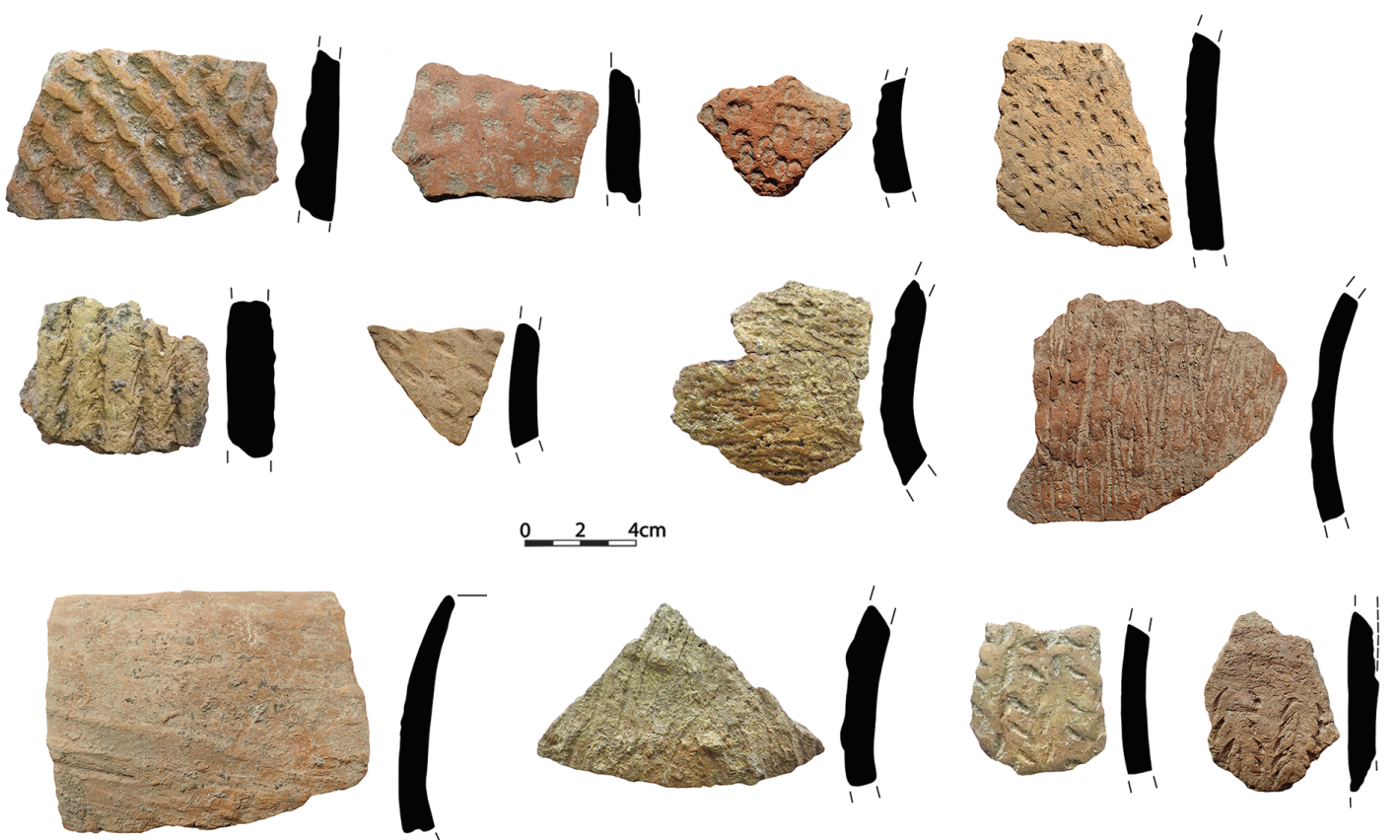

Fig. 4. Early Neolithic impressed, incised, and finger-pinched pottery from Phase II in the central origma at Mavropigi-Filotsairi.

like most caves, and this location (also next to freshwater springs) is probably related to the function of the cave. Yet like other caves in Greece, it was never used for permanent habitation but rather for short stays for various reasons (e.g., illness, ritual, herding, and refuge from inclement weather).

These facts change how Franchthi Cave was traditionally interpreted in terms not only of its date, use, and duration, but also affect the interpretation of the artefacts, such as the ceramics. For instance, it was interpreted that only a limited amount of pottery (c. 12 or 13 pots a year) was produced (Vitelli 1993b.210) by female specialists, and was thus highly valuable and used in symbolic rituals rather than for daily food-related activities (e.g., storage, processing, cooking) (Vitelli 1993a.254-255; 1999.188, 191-192, 196). These hypotheses were turned into theory by a series of archaeometric studies of sites in Thessaly (e.g., Wijnen 1981; Bjork 1995; Gardner 1978) and Central Macedonia (e.g., Yiouni 1996), and subsequently accepted as fact (e.g., Perlès 2009).

Some of these statements, however, are not applicable to other sites because of the dissonance between them either due to differences in dating or type of site (cave $v s$. open air settlement). For instance, a higher rate of vessel production was proposed at Nea Nikomedia (c. 25 to 90 per year) using a different methodology (Yiouni 2004.4; 1996.186), which is more in line with the quantity of ceramic production and use at open-air Early Neolithic sites (Yiouni
2004.10, nn. 38, 39). Similarly, the technological simplicity (e.g., use of temper, surface treatment, method of firing) of past interpretations must be questioned as new evidence from the early Middle Neolithic period (e.g., Magoula Imvrou Pigadi (Kyparissi-Apostolika 2012), Magoula Rizava (Krahtopoulou et al. 2018), and Kouphovouno (Ballut et al. 2017) suggests that kiln use was well established and probably began in the Early Neolithic period.

\section{Crete: traditional chronology and terminology}

Crete is often left out discussions of Neolithic Greece in general due to its peculiar traditional chronology and terminology. The relative chronology was almost exclusively defined in a small area within the Central Court of the Palace of Minos at Knossos excavated in the late 1950s and early 1960s (Evans 1964), and by another team in 1997 (Efstratiou et al. 2013); other areas were excavated or explored in soundings and used to fill-in or check the Central Court sequence.

The chronology of Knossos was established by Furness (1953) and built upon by John D. Evans (1964). This relative sequence used its own periodization terminology that did not match that of mainland Greece (or Anatolia), despite the existence of absolute dates from Evan's excavations since the late 1950s to help do so (nor did his subsequent experience in the Cyclades at Saliagos change his views). As a result, the levels and material labelled as Early 
Neolithic in fact correspond with the Early, Middle, and Late Neolithic periods on the mainland in terms of absolute dates (Evans 1964). The lowest level at Knossos was labelled 'Aceramic' as a parallel to the Near East and mainland Greece. The ceramics used to create the relative chronology (Furness 1953; Evans 1964; Tomkins 2007) was based primarily on decorated sherds, as undiagonstic and undecorated sherds were discarded. Much of the material was also identified as secondary refuse from exterior spaces or dumped from levelling the surface of the site. The ceramics from 1997 excavation remain unpublished.

The incongruous terminology and periodization was partially rectified by Peter D. Tomkins (2007.12; 2008 ), who tried to correlate the pottery groups from Knossos "on the basis of imports, exports, stylistic parallels and, wherever possible, radiocarbon dates to other Neolithic assemblages from elsewhere in Crete" to be more in line with dates and assemblages from mainland Greece, the Aegean islands and the Anatolian-Aegean coast. It should be noted that Tomkins himself did not apply his chronology and phases in his doctoral dissertation (Tomkins 2001) or any of his publications before 2007 (Tomkins, Day 2001; Tomkins et al. 2004), and that any articles that refer to these phases are outdated. Similarly, the Early Neolithic Houses of Sir Arthur Evans (Evans 1921) in the Central Court in fact really date to the Early Minoan period.

Furthermore, this new phasing and dating has not been universally adopted. Even as a co-editor of the volume on Neolithic Crete, which includes Tomkins' (2008) detailing of the historiography of ceramic studies at Knossos and the reasoning for his (2007) changes, few of the articles in the volume actually adopted his changes; others adhered to the old chronology (e.g., Galanidou, Manteli 2008, Strasser 2008; and the other co-editor, Isaakidou 2008) or followed their own systems (e.g., Todaro, Di Tonto 2008, Nowicki 2008). This failure of acceptance by other scholars is perhaps in part due to the fact that Tomkins (2007) did not publish any new material and even reused Evan's 1964 illustrations. Lastly, some of the parallels made by Tomkins (2007) are not all correctly dated, a fact which he may address in the future, as indicated in a footnote in which the Neolithic phase-names are changed and/or combined, and different absolute dates given but without further explanation (Tomkins 2018.129, n. 1).5

\section{The Early Neolithic on Crete revised: Knossos central court strata $X$, IX and levels 38,39}

The reevaluation of absolute dates, stratigraphy, and ceramics at Knossos mirrors that of the Franchthi Cave. First, what initially appeared to be early dates of $c .7000 \mathrm{BC}$ for Stratum X (Reingruber 2015.151; Reingruber, Thissen 2016b) are likely mistaken because the first occupation of Knossos should date closer to 6610 BC (Reingruber, Thissen 2009. 758760; Douka et al. 2017), which is in accordance with dates from site both the southern Aegean (e.g., Franchthi, Çukuriçi Höyük, and Ulucak) and northern Greece (e.g., Paliambela, Mavropigi-Filotsairi), and integrates Knossos into the earliest stage of the Early Neolithic in the wider Aegean. ${ }^{6}$

Second, there are neither dates for Stratum IX, which was previously believed to date to the Early Neolithic period, nor dates from the Middle Neolithic period. The next group of absolute dates from Knossos occur after 5300 BC (Reingruber, Thissen 2016; Douka et al. 2017.315) "an estimate that is not in conflict with the material culture of the surrounding areas", in terms of shapes and ornaments, particularly the Aegean islands (e.g., Tigani on Samos, Agia Gala on Chios, Akrotiri on Santorini) and western Anatolia (Reingruber, Thissen 2009.760-761). ${ }^{7}$

5 On numerous occasions Tomkins promises future clarification of such statements in publications which remain to appear, including (2008.27) a "completed re-evaluation of spatial (and thus demographic) development at Knossos (Tomkins in prep. with no further information)" and full publication "of Neolithic material from the British School excavations (e.g., ceramics, chipped stone, ground stone axes, faunal remains)" using with new chronology (e.g., Tomkins, in preparation as "Neolithic Knossos: Early, Middle and Late Ceramics and Stratigraphy" and "Neolithic Knossos: Final Neolithic I-IV Ceramics and Stratigraphy"). (Tomkins 2007.12). A "new typology of EN forms" to be presented elsewhere (Tomkins et al. 2004.57 with no further information) and a "new set of RC dates from Knossos in preparation (personal communication Peter Tomkins, 30 May 2015)" (Reingruber 2015.151) also awaits publication.

6 The Theopetra Cave could be another similar case in which early Neolithic absolute dates are followed by a gap of occupation followed by reuse of the cave within the middle of the Early Neolithic period) and in which the Mesolithic-Neolithic is not a contiguous transition, although the cave stratigraphy is known to be disturbed by both natural and anthropogenic processes and full publication of the stratigraphy and pottery is not yet available (Kyparissi-Apostolika 2000a; 2000b;2012; Facorellis, Maniatis 2000; Facorellis et al. 2001).

7 Recent re-excavation of the Pelekita Cave near Katos Zakros, Crete as also yielded similar Late Neolithic pottery, which according to Knossos would be dated to the Early and Middle Neolithic based on Tomkins' (2007) chronology (Bonga 2019). 
Due to the fact that Knossos was abandoned for 1000-1500 years (Douka et al. 2017.317; Reingruber et al. 2017.150; Reingruber 2015.154), continuing to use the $7000 \mathrm{BC}$ date (or limit?) for Stratum X (e.g., 7000-6600 BC: Tomkins 2007; 70006500/6400 BC: Tomkins 2014; 7000-6500: Tomkins 2018; 7030-6780 BC: Facorellis, Maniatis 2013.199) is in error (Reingruber, Thissen 2016), as is maintaining that "from the IN [Initial Neolithic] onwards habitation at Knossos seems to have been continuous and permanent" with "no obvious breaks in the stratigraphical and cultural sequences" (Tomkins 2008.21, 30; Tomkins 2007.9, 21; following Evans 1968.275). Once again, "the relative chronological system of Knossos has to be reevaluated in a general Aegean perspective" (Reingruber, Thissen 2016).

Regarding the often discussed nature of the lowest levels (Stratum X, Levels 38 and 39) at Knossos (especially Reingruber 2011; 2015; Reingruber, Thissen 2009; 2016; Evans 1964; 1971; Efstratiou et al. 2013; Tomkins 2007; Winder 1991; Bloedow 1991; Nowicki 2014), it seems increasingly unlikely that these levels represent an 'Aceramic' phase, as mudbrick and ceramic figurines were found in these levels and based on analogies with sites on the mainland formerly considered to as Aceramic or Pre-ceramic pre-ceramic as based on parallels with the PPN Pre-pottery period of the Near East or Cyprus.

\section{Conclusion}

Absolute dates from Western and Central Macedonia have pushed back the beginning of 'impresso' and painted pottery. In Southern Greece new dates on old samples and the application of Bayesian statistical analysis have demonstrated the lack of Early Neolithic occupation at both the Franchthi Cave and
Knossos, aside from brief visitations at the very beginning of the period. Gaps in occupation at sites are also increasingly being recognized based on these refined dates, re-examination of stratigraphy, and ceramic analysis.

Current studies of early ceramics are also beginning to overturn the old simplistic narratives of decorative and technological evolution. It is now demonstrated that early ceramics were a fully developed technology, although not standardized as in later periods of the Neolithic (e.g., Dimoula 2017; Pentedeka, Dimoula 2009). More complex and nuanced approaches to understanding depositional processes and cultural choice are necessary in approaching the dating and nature of Early Neolithic Greece as a socially embedded process located in a particular place and time within a certain social space (Kotsakis 2003).

The recent work on re-evaluating absolute dates through Bayesian statistical analysis and modelling is a useful way to move forward on refining chronologies at the region level and enables the accurate comparison of sites across wider geographical regions, within and outside of modern Greece. By focusing on smaller regions, perhaps patterns within these smaller areas can be better understood, with the individual site stratigraphy more accurately correlated with contemporaneous neighbouring sites. Of course, the excavation of broader areas of horizontal exposure of early sites and larger sample sizes are also necessary before constructing arguments or plugging-in data to fit preconceived expectations. Site and regional schemes, however, must take caution to not falsely be integrated into the wider world of Neolithic Greece (e.g., Franchthi Cave) or isolated from it (e.g., Knossos and Crete). 


\section{References}

Andreou S., Fotiadis M., and Kotsakis K. 1996. Review of Aegean Prehistory V: The Neolithic and Bronze Age of Northern Greece. In T. Cullen (ed.), Aegean Prehistory: A Review. American Journal of Archaeology Monographs. Archaeological Institute of America. Boston: 259-327.

Aranđelović-Garašanin D. 1954. Starčevačka kultura. Univerza v Ljubljani. Ljubljana.

Ballut C., Renard J., Cavanagh W. G., and Orgeolet R. 2017. Pottery Firing Structures in the Early Mediterranean: Micromorphological Evidence and Archaeological Data from Middle Neolithic Kouphovouno (Southern Greece). European Journal of Archaeology 20: 98-119. https://doi.org/10.1017/eaa.2016.4

Banner J. 1929. Adatok a körömmel díszített edények kronológiájához. Beiträge zur Chronologie der Nagelgeritzten Gefässe. Archaeologiai Értesítõ 43: 23-34, 322-323.

1935. Ásatás a hódmezõvásárhelyi Kotacparton. Ausgrabungen zu Kotacpart bei Hódmezõvásárhely. Dolgozatok a Szegedi Tudományegyetem Régiségtudományi Intézetébõl 11: 97-125.

Benac A. 1979. Prelazna zona. In A. Benac (ed.), Praistorija jugoslavenskih zemalja II. Akademija nauka i umjetnosti Bosne i Hercegovine. Sarajevo: 363-470.

Björk C. 1995. Early Pottery in Greece. A Technological and Functional Analysis of the Evidence from Neolithic Achilleion, Thessaly (SIMA 116). P. Åström Forlag. Stockholm.

Bloedow E. F.1991. The "Aceramic" Neolithic Phase in Greece Reconsidered. Mediterranean Archaeology 4: 1-43.

Bonga L. 2017. Thoughts on the Preliminary Study of Early Neolithic Decorated Pottery from the Central Origma at Mavropigi-Filotsairi. In A. Sarris, E. Kalogiropoulou, T. Kalayci, and L. Karimali (eds.), Proceedings from the International Conference, Communities, Landscapes and Interaction in Neolithic Greece. Institute for Mediterranean Studies, Rethymno, Crete, 29-30 May 2015. Archaeological Series 20. Ann Arbor, Michigan: 371-384.

2019. Neolithikē Keramikē apo to Spēlaio Pelekēta, Katō Zakro, Krētē. Proceedings of 12th International Congress of Cretan Studies, Heraklion, Crete, Greece, September 21-25, 2016: 1-11. https://12iccs.proceedi ngs.gr/el/proceedings/category/38/32/834 (in Greek)

Chrysostomou P. 1996. Ē neolithikē katoikisē stēn voreia paraktia zōnē tou allote Thermaïkou Kolpou (eparchia Giannitsōn). To Archaiologiko Ergo stē Makedonia kai Thrake 10: 159-172. (in Greek)
1997. Nea stoixeia apo tē neolithikē ereuva stēn eparchia Giannitsōn. Mia agnostē morphē proistorikēs graphēs. To Archaiologiko Ergo stē Makedonia kai Thra$k \bar{e}$ 15(2001): 489-500. (in Greek)

Childe V. G. 1929. The Dawn of European Civilization. K. Paul, Trench, Trubner \& Co. London.

Çilingiroğlu C. 2010. The Appearance of Impressed pottery in the Neolithic Aegean and Its Implications for Maritime Networks in the Eastern Mediterranean. Türkiye Bilimler Akademisi Arkeoloji Dergisi. Türkish Academy of Sciences Journal of Archaeology 13: 9-22.

2016. Impressed Pottery as a Proxy for Connectivity in the Neolithic Aegean and Eastern Mediterranean. In B. P. C. Molly (ed.), Of Odysseys and Oddities. Scales and Modes of Interaction between Prehistoric Aegean Societies and Their Neighbours. Sheffield Studies in Aegean Archaeology. Philadelphia: 75-96.

Coleman J. E. 1992. Greece, the Aegean, and Cyprus: Part 1. In R. W. Enrich, (ed.), Chronologies in Old World Archaeology. University of Chicago Press. Chicago and London: 203-221, 247-278.

2011. The Petromagoula-Doliana Group and the Beginning of the Aegean Early Bronze Age. In D. Katsonopoulou (ed.), Helike IV. Ancient Helike and Aigialeia. Protohelladika: The Southern and Central Greek Mainland. The Helike Society. Athens: 13-44.

Coleman, J. E., Facorellis Y. 2018. The Shadowy "ProtoEarly Bronze Age" in the Aegean. In S. Dietz, F. Mavridis, Z. Tankosić, and T. Takaoğlu (eds.), Communities in Transition: The Circum-Aegean Area in the $5^{\text {th }}$ and $4^{\text {th }} \mathrm{Mil}$ lennia BC. Danish Institute at Athens, 7-9/6 2013. Monographs of the Danish Institute at Athens 20. Oxbow. Oxford: 33-66.

Dimitrijević S. 1969. Starčevačja kultura u Slavonsko-Srijemskom prostoru i problem prijelaza starijeg u srednji neolit u Srpskom i Hrvatskom Podunavlju. In D. Švagelj, A. Dorn (eds.), Neolit i Eneolit u Slavoniji. Gradski muzej. Vukovar: 9-96.

1974. Problem stupnjevanja Starčevačke Kulture s posebnim obzirom na doprinos Južnopanonskih nalazišta rešavanju ovih problema. Materijali 40: 59-122.

Dimoula A. 2017. Early Pottery Mobility: The Case of Early Neolithic Thessaly, Greece. Journal of Archaeological Science 12: 209-218.

https://doi.org/10.1016/j.jasrep.2017.01.008 
Douka K., Efstratiou N., Hald M. M., Henriksen P. S., and Karetsou A. 2017. Dating Knossos and the Arrival of the Earliest Neolithic in the Southern Aegean. Antiquity 91 (356): 304-321. https://doi.org/10.15184/aqy.2017.29

Efstratiou, N., Karetsou A. and Ntinou M. (eds.). 2013. The Neolithic Settlement of Knossos in Crete. New Evidence for the Early Occupation of Crete and the Aegean Islands. Institute for Aegean Prehistory Academic Press. Philadelphia.

Evans A. 1921. The Palace of Minos. A Comparative Account of the Successive Stages of the Early Cretan Civilization as Illustrated by the Discoveries at Knossos. Volume 2. The Neolithic and Early Middle Minoan Ages. Macmillan. London.

Evans, J. D. 1964. Excavations in the Neolithic Settlement of Knossos 1957-1960, Part I. The Annual of the British School at Athens 59: 132-240.

1968. Neolithic Knossos, Part II. Summary and Conclusions. British School at Athens Annual 63: 267-276.

1971. Neolithic Knossos: The Growth of a Settlement. Proceedings of the Prehistoric Society 37: 95-117.

Facorellis Y., Maniatis Y. 2000. Evidence for 50000 Years of Human Activity in the Cave of Theopetra by ${ }^{14} \mathrm{C}$. In $\mathrm{N}$. Kyparissi-Apostolika (ed.), Theopetra Cave: Twelve Years of Excavation and Research 1987-1998. Proceedings of the International Conference, Trikala, 6-7 November 1998. Greek Ministry of Culture. Athens: 53-68.

2013. Radiocarbon Dates from the Neolithic Settlement of Knossos: An Overview. In N. Efstratiou, A. Karetsou, and M. Ntinou (eds.), The Neolithic Settlement of Knossos in Crete. New Evidence for the Early Occupation of Crete and the Aegean Islands. Institute for Aegean Prehistory Academic Press. Philadelphia: 193-200.

Facorellis Y. Kyparissi-Apostolika N., and Maniatis Y. 2001. The Cave of Theopetra, Kalambaka: Radiocarbon Evidence for 50,000 Years of Human Presence. In I. Carmi, E. Boaretto (eds.), Proceedings of the $17^{\text {th }}$ International ${ }^{14} \mathrm{C}$ Conference. Radiocarbon 43(28): 1029-1048.

Furness A. 1953. The Neolithic Pottery of Knossos. The Annual of the British School at Athens 48: 94-134.

Galanidou N., Manteli K. 2008. Neolithic Katsambas Revisited: The Evidence from the House. In V. Issakidou, P. Tomkins (eds.), Escaping the Labyrinth: The Cretan Neolithic in Context. Sheffield Studies in Aegean Archaeology 8. Oxbow. Oxford: 172-183.

Gallis K. 1987. Die stratigraphische Einordnung der Larisa Kulture: eine Richtigstellung. Prähistorische Zeitschrift 62: 147-163.
1992. Atlas proïstorikon oikismōn tēs anatolikē Thessalikē pedias. Society of Thessalian Historical Studies. Larisa. (in Greek)

Garašanin M. V. 1979. Centralnobalkanska zona. In A. Benac (ed.), Praistorija jugoslovenskih zemalja II. Neolitsko doba. Akademija nauka i umjetnosti Bosne i Hercegovine. Sarajevo: 79-212.

1982. The Stone Age in the Central Balkan Area. In I. E. S., Edwards, C. J. Gadd, and N. G. L. Hammond (eds.), Cambridge Ancient History III (1). Cambridge University Press. Cambridge: 75-162.

Gardner E. J. 1978. The Pottery Technology of the Neolithic Period in Southeastern Europe. Unpublished PhD dissertation. University of California. Los Angeles.

Gaskevych D. 2010. Severo-pontiyskoe impresso: proiskhozhdenie neoliticheskoy keramiki s grebenchatim ornamentom na yuge Vostochnoy Yevropy. Stratum plus. Archaeology and Cultural Anthropology 2: 213-251. (in Russian with English summary)

2011. A New Approach to the Problem of the Neolithisation of the North-Pontic Area: Is there a North-eastern Kind of Mediterranean Impresso Pottery? Documenta Praehistorica 38: 275-290.

https://doi.org/10.4312/dp.38.22

Grbić M 1957. Preclassical Pottery in the Central Balkans. Connections and Parallels with Agea, the Central Danube and Anatolia. American Journal of Archaeology 61: 137149.

Güldoğan E. 2008. An Experimental Study of the Decorative Techniques in Comb-impressed "Impresso" Ware Group Mezraa-Teleilat. Türkiye Bilimler Akademisi Arkeoloji Dergisi 11: 155-166. (in Turkish with English summary)

Isaakidou V. 2008. The Fauna and Economy of Neolithic Knossos' Revisited. In V. Issakidou, P. Tomkins (eds.), Escaping the Labyrinth: The Cretan Neolithic in Context. Sheffield Studies in Aegean Archaeology 8. Oxbow. Oxford: $90-114$.

Karamitrou-Mentessidi G., Efstratiou N., Kaczanowska M., and Kozłowski J. K. 2016. Early Neolithic Settlement of Mavropigi in Western Greek Macedonia. Eurasian Prehistory 1-2: 47-116.

Krahtopoulou A., Dimoula A., Livarda A., and Saridaki N. 2018. The Discovery of the Earliest Specialised Middle Neolithic Pottery Workshop in Western Thessaly, Central Greece. Antiquity 92(362): 1-7. https://doi.org/10.15184/aqy.2018.54 
Kotsakis K. 1983. Keramikē technologia kai keramikē diamoropoisē. Problēmata tēs graptēs keramikēs tēs mesēs neolithikēs epoxēs tou Sesklou. Unpublished PhD dissertation. Aristotle University. Thessaloniki. (in Greek)

2003. From the Neolithic Side: The Mesolithic/Neolithic Interface in Greece. In N. Galanidou, C. Perlès (eds.), The Greek Mesolithic: Problems and Perspectives. British School at Athens Studies 10. British School at Athens. London: 217-221.

2008. A Sea of Agency: Crete in the Context of the Earliest Neolithic in Greece. In V. Issakidou, P. Tomkins (eds.), Escaping the Labyrinth: The Cretan Neolithic in Context. Sheffield Studies in Aegean Archaeology 8. Oxbow. Oxford: 49-72.

Krauß R. 2006. Die prähistorische Besiedlung am Unterlauf der Jantra vor dem Hintergrund der Kulturgeschichte Nordbulgariens. Prähistorische Archäologie in Südosteuropa 20. Marie Leidorf. Rahden.

2008. Karanovo und das südosteuropäische Chronologiesystem aus heutiger Sicht. Eurasia Antiqua 14: 115147.

2011. On the "Monochrome" Neolithic in Southeast Europe. In R. Krauß (ed.), Beginnings - New Research in the Appearance of the Neolithic between Northwest Anatolia and the Carpathian Basin. Papers of the International Workshop $8^{\text {th-9 }}$ th April 2009, Istanbul. Organized by D. Ciobotaru, B. Horejs and R. Krauss. Menschen-Kulturen-Traditionen 1. Studien aus den Forschungsclustern des Deutschen Archäologischen Instituts. Marie Leidorf. Rahden/ Westfalen: 109-125.

Krauß R., Elenski N., Weninger B., Clare L., Çakırlar C., and Zidarov P. 2014. Beginnings of the Neolithic in Southeast Europe. The Early Neolithic Sequence and Absolute Dates from Džuljunica-Smărdeš (Bulgaria). Documenta Praehistorica 41: 51-77. https://doi.org/10.4312/dp.41.3

Kyparissi-Apostolika N. 2000a. The Mesolithic/Neolithic transition in Greece as indicated by the data in Theopetra Cave. Documenta Praehistorica 27: 133-140. https://www. dlib.si/stream/URN:NBN:SI:doc-TFBNG4Z0/1a515145fd38-4ab1-8e75-b3c371739463/PDF

2000b. The Neolithic Period in Theopetra Cave. In N. Kyparissi-Apostolika (ed.), Theopetra Cave: Twelve Years of Excavation and Research 1987-1998. Proceedings of the International Conference, Trikala, 6-7 November 1998. Greek Ministry of Culture. Athens: 181234.

2012. Indications of the Presence of Middle Neolithic Pottery Kilns at Magoula Imvrou Pigadi, SW Thessaly,
Greece. Documenta Praehistorica 39: 433-442.

https://doi.org/10.4312/dp.39.31

Lazarovici G. 1979. Neoliticul Banatului. Biblioteca Musei Napocensis 4. Cluj-Napoca. Romania.

Lespez L., Tsirtsoni Z., Darcque P., and Koukouli-Chryssanthaki H. 2013. The Lowest Levels at Dikili Tash, Northern Greece: A Missing Link in the Early Neolithic of Europe. Antiquity 87: 30-45.

https://doi.org/10.1017/S0003598X00048602

Makkay J. 1965. Die wichtigsten Fragen der Körös-Starčevo-Periode. Acta Antiqua et Archaeologica 8: 3-18.

1969. Zur Geschichte der Erforschung der Körös-Starčevo-Kultur und einiger ihrer wichtigsten Probleme. Acta Archaeologica Academiae Scientiarum Hungaricae 21: $13-31$.

1987. Kontakte zwischen der Körös-Starčevo-Kultur und der Linienbandkeramik. Communicationes Archaeologicae Hungariae: 15-24.

Maniatis Y. 2014. Chronologisē me anthraka-14 tōn megalōvn politismikōn allagōn stēn proïstorikē Makedonia prosfates exelixeis. In E. Stephani, N. Merousis, and A. Dimoula (eds.), 1912-2012: Ekato chronia eruenas stēn proïstorikē Makedonia. Praktika Diethnous Sunedriou Archaeiologiko Mouseio Thessalonikēs, 22-24 Noemvriou 2012. Ekdosē Archaiologikou Mouseiou Thessalonikēs 22. Thessaloniki: 205-222. (in Greek)

Maniatis Y., Kotsakis K., and Halstead P. 2015. Paliambela Kolindrou. Nees chronologēseis tēs archaēoteris Neolithikēs. To Archaiologiko Ergo stē Makedonia kai Thrakē 25: 149-156. (in Greek)

Milojčić V. 1949a. Chronologie der Jüngeren Steinzeit Mittel-und Südosteuropas. Verlag Gebr. Mann. Berlin.

1949b. South-Eastern Elements in the Prehistoric Civilization of Serbia. The Annual of the British School at Athens 44: 258-306.

1950/51. Zur Chronologie der jüngeren Steinzeit Griechenlands. Jahrbuch des Deutschen Archäologischen Instituts 65/66: 1-90.

1959. Ergebnisse der deutschen Ausgrabungen in Thessalien, 1952-1958. Jahrbuch des Römisch-Germanischer Zentralmuseums Mainz 6: 1-56.

1960. Präkeramisches Neolithikum auf der Balkanhalbinsel. Germania 38: 320-335. 
Milojčić V., Milojčić-von Zumbusch J. (eds.), Die deutschen Ausgrabungen auf der Otzaki-Magula in Thessalien I. Das frühe Neolithikum. Beiträge zur ur- und frühgeschichtlichen Archäologie des Mittelmeer-Kulturraumes 1011. Habelt. Bonn.

Milojčić-von Zumbusch J. 1971. Vorlage der Funde. In V. Milojčić, J. Milojčić-von Zumbusch (eds.), Die deutschen Ausgrabungen auf der Otzaki-Magula in Thessalien I. Das frühe Neolithikum. Beiträge zur ur- und frühgeschichtlichen Archäologie des Mittelmeer-Kulturraumes 10-11. Habelt. Bonn: 19-152.

Mottier Y. 1981. Die deutschen Ausgrabungen auf der Otzaki Magula in Thessalien II: Das mittlere Neolithikum. Beiträge zur ur- und frühgeschichtlichen Archäologie des Mittelmeer- Kulturraumes 22. Rudolf Habelt. Bonn.

Müller J. 1988. Cultural Definition of the Early Neolithic and its Interaction in the Eastern Adriatic. Berytus 36: 101-125.

1994. Das Ostadriatische Frühneolithikum. Die Impresso-Kultur und die Neolithisierung des Adriaraumes. Prähistorische Archäologie in Südosteuropa 9. Berlin.

Nandris J. 1970. Ground Water as a Factor in the First Temperate Neolithic Settlement of the Körös Region. Zbornik Narodnog Muzeja 6: 59-71.

Naumov G. 2009. Patterns and Corporeality: Neolithic Visual Culture from the Republic of Macedonia. British Archaeological Reports IS 1910. Archaeopress. Oxford.

Nowicki K. 2008. The Final Neolithic (Late Chalcolithic) to Early Bronze Age Transition in Crerte and the SouthEast Aegean Islands: Changes in Settlement Patterns and Pottery. In V. Isaakidou, P. D. Tomkins (eds.), Escaping the Labyrinth: The Cretan Neolithic in Context. Oxbow. Oxford: $22-48$.

2014. Final Neolithic Crete and the Southeast Aegean. De Gruyter. Berlin.

Papadakou T. A. 2011. E keramikē tēs Archaioterēs Neolithikēs apo tē thesē Paliambela Kolindrou. Thesis. Aristotle University. Thessaloniki. (in Greek)

Papdakou T., Ourem-Kotsou D., and Kotsakis K. 2015. Keramikē tēs Archaioterēs Neolithikēs apo ta Paliambela Kolindrou. To Archaiologiko Ergo stē Makedonia kai Thra$k \bar{e}$ 25: 157-162. (in Greek)

Pentedeka A., Dimoula A. 2009. Early Pottery Technology and the Formation of a Technological Tradition: The Case of Theopetra Cave, Thessaly, Greece. In P. Quinn (ed.), In- terpreting Silent Artefacts: Petrographic Approaches to Archaeological Ceramics. Archaeopress. Oxford: 121137.

Perlès C. 2001. The Early Neolithic in Greece: The First Farming Communities in Europe. Cambridge World Archaeology. Cambridge.

2009. De la technologie céramique à la néolithisation de la Grèce. In L. Astruc, A. Gaulon, and L. Salanova (eds.), Méthodes d'approche des premières productions céramiques: étude de cas dans les Balkans et au Levant. Table-ronde de la Maison de l'Archéologie et de l'Ethnologie (Nanterre, France) 28 février 2006. Internationale Archäologie: Arbeitsgemeinschaft, Symposium, Tagung, Kongress Bd. 12. Leidorf: 51-62.

Perlès C., Quiles A., and Valladas H. 2013. Early SeventhMillennium AMS Date from Domestic Seeds in the Initial Neolithic at Franchthi Cave (Argolid, Greece). Antiquity 87: 1001-1015.

https://doi.org/10.1017/S0003598X00049826

Raczky P. 2012. Körös culture research history. In A. Anders, Z. Siklósi (eds.), The First Neolithic Sites in Central/South-East European Transect. Volume III The Körös Culture in Eastern Hungary. British Archaeological Reports IS 2334. Archaeopress. Oxford: 9-38.

Reingruber A. 2008. Die Argissa Magula: Das frühe und das beginnende Neolithikum im Lichte transägäischer Beziehungen. Die deutschen Ausgrabungen auf der Argissa Magula II. Beiträge zur ur- und frühgeschichtlichen Archäologie des Mittelmeerraums 35. Habelt. Bonn.

2011. Early Neolithic Settlement Patterns and Exchange Networks in the Aegean. Documenta Praehistorica 38: 291-305. https://doi.org/10.4312/dp.38.23

2015. Preceramic, Aceramic or Early Ceramic? The radiocarbon dated beginning of the Neolithic in the Aegean. Documenta Praehistorica 42: 147-158.

https://doi.org/10.4312/dp.42.9

Reingruber A., Thissen L. 2009. Depending on ${ }^{14} \mathrm{C}$ Data: Chronological Frameworks in the Neolithic and Chalcolithic of Southeastern Europe. Radiocarbon 21(2): 751770. https://doi.org/10.2458/azu_js_rc.51.3531

2016. The 14SEA Project. A ${ }^{14} \mathrm{C}$ Database for Southeast Europe and Anatolia (10,000-3000 calBC). Analysis. Subregion IIb - Southern Aegean. The Neolithic period in the Southern Aegean Region. Franchthi, Knossos, Kouphovouno, General Assement. http://www.14sea. org/3_IIb.html\#site2, http://www.14sea.org/3_IIb.html, last updated 1-31-2017 
Reingruber A., Toufexis G., Kyparissi-Apostolika N., Anetakis M., Maniatis Y., and Facorellis Y. 2017. Neolithic Thessaly. Radiocarbon Dated Periods and Phases. Documenta Praehistorica 44: 34-53. https://doi.org/10.4312/dp.44.3

Saridaki N., Kotsakis K., Urem Kotsou D., Papadakou T., and Papaioannou A. 2019. Production Practices during the Neolithic in Pieria, Macedonia (Northern Greece). In S. Amicone, P. Quinn, M. Radivojević, M. Marić, and N. Mirković (eds.), Tracing Pottery Making Recipes in the Balkans, $6^{\text {th }}$ th $^{\text {th }}$ Millennium BC. International Workshop Belgrade, 19-20 September 2014. Archaeopress. Oxford.

Schubert H. 1999. Die Bemalte Keramik des Frühneolithikums in Südosteuropa, Italien und Westanatolien. International Archaeology 47. Marie Leidorf. Rahden/Westf.

2005. Everyone's Black Box - Where does the European Ornamentation Come From? In C. Lichter (ed.), How Did Farming Reach Europe? Anatolian-European Relations from the Second Half of the Seventh through the First Half of the Sixth Millennium cal BC. International Workshop, Istanbul, 20-22 May 2004. BYZAS 2. Deutsches Archäologisches Institut Abteilung. Istanbul: 239-254.

Spataro M. 2009. Cultural Diversities: The Early Neolithic in the Adriatic Region and Central Balkans. A Pottery Perspective. In D. Gheorghiu (ed.), Early Farmers, Late Foragers, and Ceramic Traditions: On the Beginning of Pottery in the Near East and Europe. Cambridge Scholars Publishing. Cambridge: 63-86.

Sekereš L. 1974. Neki aspekti istraživanja ranog neolita u severoistočnoj Bačkoj. Materijali 50: 189-196.

Srejović D. 1971. Die Lepenski Vir-Kultur und der Beginn der Jungsteinzeit an der mittleren Donau. In H. Schwabedissen (ed.), Die Anfänge des Neolithikums vom Orient bis Nordeuropa. Fundamenta A/3. Böhlau. Köln: 1-19.

Strasser T. 2008. Stones of Contention: Regional Axe Production and Hidden Landscapes on Neolithic Crete. In V. Issakidou, P. Tomkins (eds.), Escaping the Labyrinth: The Cretan Neolithic in Context. Sheffield Studies in Aegean Archaeology 8. Oxford. Oxbow: 155-164.

Stefanova T. 1996. A Comparative Analysis of Pottery from the "Monochrome Early Neolithic Horizon" and "Karanovo I Horizon" and the Problems of the Neolithization of Bulgaria. Poročilo o raziskovanju paleolitika, neolitika in eneolitika $v$ Sloveniji 23: 1-38.

Stojanovski D., Nacev T., and Arzarello M. 2014. Pottery Typology and the Monochrome Neolithic Phase in the Republic of Macedonia. In W. Schier, F. Drassovean (eds.), The Neolithic and Eneolithic in Southeast Europe: New
Approaches to Dating and Cultural Dynamics in the $6^{\text {th }}$ to $4^{\text {th }}$ Millennium BC. Prähistorische Archäologie in Südosteuropa 28. Marie Leidorf. Rahden/Westf: 9-27.

Theocharis D. R. (ed.) 1973. Neolithic Greece. National Bank of Greece. Athens.

Todaro S., Di Tonto S. 2008. The Neolithic Settlement of Phaistos Revisited: Evidence for Ceremonial Activity on the Eve of the Bronze Age. In V. Issakidou, P. Tomkins (eds.), Escaping the Labyrinth: The Cretan Neolithic in Context. Sheffield Studies in Aegean Archaeology 8. 0xbow. Oxford: 177-190.

Tomkins P. 2001. The Production, Circulation and Consumption of Ceramic Vessels at Early Neolithic Knossos, Crete. Unpublished $\mathrm{PhD}$ dissertation. University of Sheffield. Sheffield.

2007. Neolithic. Strata IX-VIII, VII-VIB, VIA-V, IV, IIIB, IIIA, IIB, IIA and IC Groups. In N. Momigliano (ed.), Knossos Pottery Handbook Neolithic and Bronze Age (Minoan). British School at Athens Studies 14. British School at Athens. London: 9-48.

2008. Time, Space and the Reinvention of the Cretan Neolithic. In V. Isaakidou, P. D. Tomkins (eds.), Escaping the Labyrinth: The Cretan Neolithic in Context. Oxbow. Oxford: 22-48.

2014. Tracing Complexity in "the Missing Millennium." An Overview of Recent Research into the Final Neolithic Period on Crete. In B. Horejs, M. Mehofer (eds.), Western Anatolia before Troy: Proto-Urbanisation in the $4^{\text {th }}$ Millennium $B C$ ? Proceedings of the International Symposium held at the Kunsthistorisches Museum Wien, Vienna, Austria, 21-24 November 2012. Oriental and European Archaeology 1. Austrian Academy of Sciences Press. Vienna: 345-364.

2018. Palimpsests and Proxies. A Reconsideration of Neolithic Settlement in the Mesara Before Phaistos. In G. Baldacci, I. Caloi (eds.), Rhadamanthys: Studi di archeologia minoica in onore di Filippo Carinci per il suo $70^{\circ}$ compleanno. Studies in Minoan Archaeology in Honour of Filippo Carinci on the Occasion of His 70th Birthday. British Archaeological Reports IS 2884. Archaeopress. Oxford: 129-136.

Tomkins P., Day P. M. 2001. Production and Exchange of the Earliest Ceramic Vessels in the Aegean: A View from Early Neolithic Knossos, Crete. Antiquity 75: 259-260. https://doi.org/10.1017/S0003598X0006083X

Tomkins P., Day P. M., and Kilikoglou V. 2004. Knossos and the Early Neolithic Landscape of the Herakleion Basin. In G. Cadogan, E. Hatzaki, and A. Vasilakis (eds.), 
Knossos: Palace, City, State. British School at Athens. London: 51-59.

Tsirtsoni Z. (ed.) 2016. The Human Face of Radiocarbon. Reassessing Chronology in Prehistoric Greece and Bulgaria, 5000-3000 cal BC. (Maison de l'Orient et de la Méditerranée, Travaux de la Maison de l'Orient et de la Méditerranée 69). Maison de l'Orient et de la Méditerranée-Jean Pouilloux. Lyon.

2017. Let's Stop Speaking 'Cultures'! Alternative Means to Assess Historical Developments in the Prehistoric Balkans. In M. Gori, M. Ivanova (eds.), Balkan Dialogues. Negotiating Identity between Prehistory and the Present. Routledge. New York: 64-85.

Tsountas C. 1908. Hai prö̈storikai akropoleis Dimēniou kai Sesklou. Vivliothēkē tēs en Athēnais Archaiologikēs Hetaireias 43. Sakellarios. Athens. (in Greek)

Vitelli K. D. 1993a. Power to the Potters. Comment on Perlès' "Systems of Exchange and Organization of Production in Neolithic Greece." Journal of Mediterranean Archaeology 6: 247-257.

1993b. Franchthi Neolithic Pottery I: Classification and Ceramic Phases 1 and 2 Excavations at Franchthi Cave, Greece (Fascicle 8). Bloomington. Indiana.

1999. Looking Up at Early Ceramics in Greece. In J. Skibo, G. Feinman (eds.), Pottery and People. Foundations of Archaeological Inquiry. Salt Lake City, Utah: 184198.

Vuković J. 2006. Funkcionalna analiza neolitske grnčarije centralnog Balkana - metodi, tehnike $i$ primena. $\mathrm{PhD}$ thesis. University of Belgrade. Belgrade.
2013. Deskripcija nasuprot interpretaciji: Odnos tradicionalne i savremene arheologije prema problemu impreso-barbotin ranog neolita. Issues in Ethnology and Anthropology 8(3): 657-679.

Wace A. J. B., Thompson M. S. 1912. Prehistoric Thessaly. Being some Account of Recent Excavations and Explorations in North-eastern Greece from Lake Kopais to the Borders of Macedonia. Cambridge University Press. Cambridge.

Weinberg S. S. 1962. Excavations at Prehistoric Elateia, 1959. Hesperia 31(2): 158-209.

1970. The Stone Age in the Aegean. In Cambridge Ancient History I, Part 1. Cambridge University Press, Revised Edition. Cambridge: 557-618, 664-72.

Winder N. P. 1991. Interpreting a Site: The Case for a Reassessment of the Knossos Neolithic. Archaeological Review from Cambridge 10(1): 37-52.

Wijnen M. 1981. The Early Neolithic I Settlement at Sesklo: An Early Farming Community in Thessaly, Greece. Analecta Praehistoric Leinesia 14. Leiden.

Yiouni P. 1996. The Early Neolithic Pottery: Technology. Analysis and Comparison with other Neolithic Ceramic Materials. In R. J. Rodden, K. A. Wardle (eds.), Nea Nikomedeia I. The Excavation of an Early Neolithic Village in Northern Greece 1981-1964. The Annual of the British School at Athens Supp. 25. London: 55-193.

2004. Counting Pots in Early Neolithic Greece. The Annual of the British School at Athens 99: 1-22.

\section{back to contents}

